\title{
AN UPDATE TO SEISMIC HAZARD LEVELS AND PSHA FOR LOMBOK AND SURROUNDING ISLANDS AFTER EARTHQUAKES IN 2018
}

\author{
Didi S. Agustawijaya ${ }^{1}$, Rian M. Taruna ${ }^{2}$ and \\ Ausa R. Agustawijaya ${ }^{3}$
}

(Submitted October 2019; Reviewed January 2020; Accepted August 2020)

\begin{abstract}
A series of earthquakes occurred at the northern part of Lombok Island during July-September 2018 with the highest Mw7.0 $5^{\text {th }}$ August 2018 that caused the death of hundreds of people and ruined thousands of buildings. The earthquakes were triggered on the Flores Thrust located at the back arc zone and at only $50 \mathrm{~km}$ distance from the island, leading to multiple seismic hazards to Lombok and surrounding islands. The thrust could possibly be the dominant current seismic sources; however, the megathrust sources also contributed to the hazards due to the subduction between the Indo-Australia and Eurasia tectonic plates in the Nusa Tenggara region. An updated probabilistic seismic hazard analysis was, therefore, conducted on recent seismicity, detailed tectonic background, and suitable ground motion prediction equations, to determine higher seismic parameter values than the 2017 models. This means that Lombok and surrounding islands exposed to higher seismic hazards than those predicted before the earthquake events in 2018.
\end{abstract}

\section{INTRODUCTION}

A series of shallow earthquakes occurred during JulySeptember 2018 at the northern part of Lombok Island, Indonesia, with magnitudes ranging $4-7$, and the sequence lasted from July to December 2018 [1]. About 365 events occurred between $29^{\text {th }}$ July and $9^{\text {th }}$ August 2018, and the largest event occurred in $5^{\text {th }}$ August 2018 with a magnitude of 7.0, destroying almost 800 thousand homes, and causing the death of more than 500 people $[2,3]$. Most of the events occurred at the mainland or closed to the island where damages to homes, buildings, roads and bridges were inevitable, as shown in Figure 1.
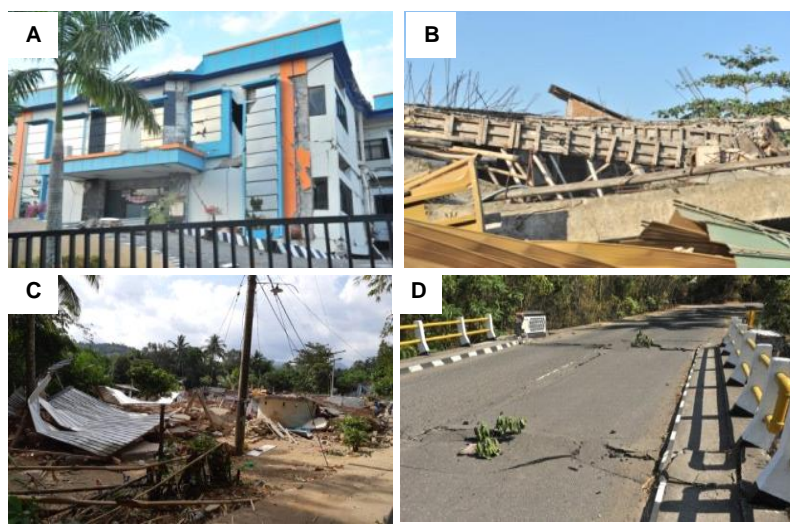

Figure 1: The earthquake occurred in $5^{\text {th }}$ August 2018 has ruined: A) buildings in Mataram, B) shops in Gunung Sari, $C)$ homes in Pemenang; and D) roads and bridges in Kayangan in Lombok Island.

Lombok Island is located in the Nusa Tenggara region, which is one of the most active seismic area in Indonesia [4]. The tectonic setting of the region is part of the Sunda Arc, where the
Indo-Australia ocean plate subducts beneath the Eurasia continental plate [5]; while, the Pacific plate moves to the west direction to compresses the Banda Arc then the Sunda Arc [6], as indicated in Figure 2.

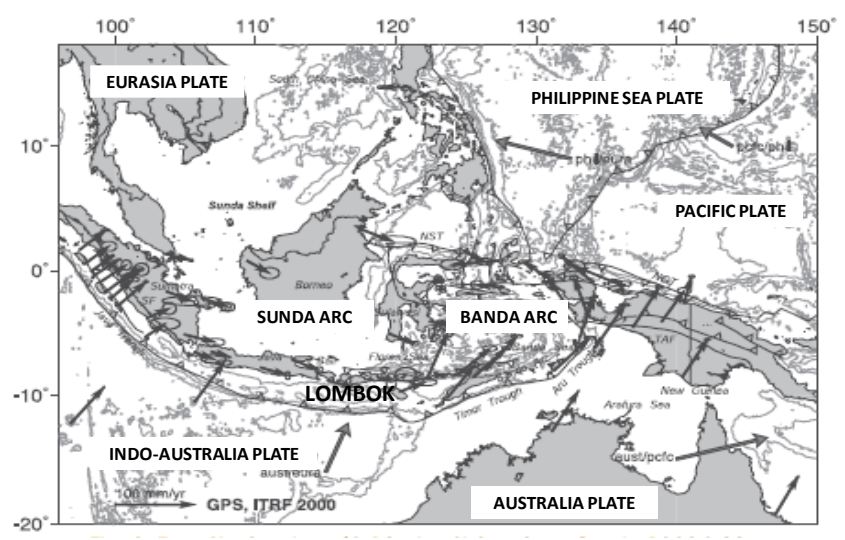

Figure 2: Tectonic pattern and geodetic ground movements of Indonesia modified from Bock et al. [6], where Lombok Island just located between the Sunda Arc and the Banda Arc.

Most of the recent Lombok earthquake events occurred at the back arc basin called the Bali Basin [4], (Figure 3). The Bali Basin is located along the northern part of Bali and Lombok Islands, connected with the Flores Basin at the northern sea of Flores Island. There is, however, an up-thrusting fault called the Flores Fault [5] or Flores Thrust (FT) [7] along these two basins. The west end of the thrust seems just to be within the back-arc zone of Lombok Island at only approximately $50 \mathrm{~km}$ distance from the island. Some researchers [7, 8] argued that the FT might be connected with the Kendeng Depression Zone, a major geological structure that cuts along Central and East Java

\footnotetext{
1 Corresponding Author, Professor, Department of Civil Engineering, University of Mataram, Mataram, Indonesia, didiagustawijaya@ unram.ac.id

2 Researcher, The Indonesian Agency for Meteorology, Climate and Geophysics (BMKG), Mataram, Indonesia, reemyan@ gmail.com

3 Student, Department of Geomatics Engineering, ITS, Surabaya, Indonesia, ausaramadhan@gmail.com
} 
[9]. The FT mechanisms could, however, be determined by the East Indonesia tectonic setting $[10,11]$.

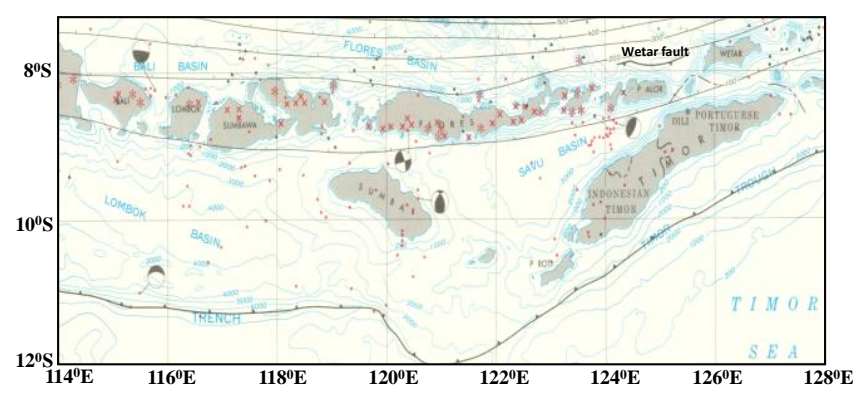

Figure 3: The bathymetry map of earthquakes in Indonesia developed in 1974 [4], showing the connection between the Bali Basin and Flores Basin in the Nusa Tenggara islands, where the Wetar Fault was first recognised at the northern part of Wetar Island, then extended to the Flores Fault located at the northern part of Flores and Lombok Islands $[5,8]$.

There are generally two main sources of earthquakes around Lombok Island: the south subduction-megathrust that generates deep as well as shallow earthquakes; and the north back arc thrust that conversely tends to generate shallow earthquakes [12]. Tectonic forces consequently create a lot of instability within this intensely compressed island. This may be the reason that the 2018 seismic events ruined almost one third of the island, particularly the West, North and East Lombok Districts. The past occurrences in the area were due to the back arc thrust in 1979 [13], an outer-rise earthquake in 1977 [14]; however, the influence of the reverse back arc thrust was observed to be more prominent in the seismicity of Lombok and surrounding islands than it was previously predicted [15].

An evaluation on seismic conditions of Lombok and surrounding islands should, therefore, be important to understand earthquake potential of the eastern part of the Sunda Arc system [16]. Consequently, an updated model was proposed by applying probabilistic seismic hazard analyses to review the existing seismic parameters [17] in order to have recent and up to date information about seismicity in the area.

\section{METHODS}

The earthquake catalogues for the period of 1922-2018 were derived from the United State Geological Survey (USGS) [18], the International Seismological Centre (ISC) [19], and the Indonesian Centre for Meteorology, Climate and Geophysics (BMKG) [1]. The earthquakes were recorded in various magnitude types of over 3.0 at depths of $<400 \mathrm{~km}$, which were then modified into moment magnitudes (Mw) according to [20, 21].

The seismicity of Lombok and surrounding islands was determined using the Gutenberg-Richter empirical relation [22]:

$$
\log \mathrm{N}_{(\mathrm{M})}=a-b \mathrm{M}
$$

where $\mathrm{N}_{(\mathrm{M})}$ is the number of earthquakes with magnitude greater than or equal to M. The $a$-value is a seismic intensity parameter, which depends on the number of earthquake events. The $b$-value is a seismicity parameter determined as the linear slope on the graph of the $\mathrm{N}_{(\mathrm{M})}$ number and magnitude $\mathrm{M}$, or by utilizing the maximum likelihood method [23, 24]:

$$
b=\frac{\log \mathrm{e}}{\mathrm{M}_{\mathrm{ave}}-\mathrm{M}_{0}}
$$

$\mathrm{M}_{\mathrm{ave}}$ is the average magnitude, and $\mathrm{M}_{0}$ is the minimum magnitude.
A number of empirical attenuation relations have been suggested by many researchers, each with different characteristics, which depend on typical earthquake patterns of the location being investigated [25]. For Indonesia, six different attenuation relations have been suggested for three different earthquake sources: subduction, fault and shallow background, and deep background [21]. The Joyner-Boore relation [26] was applied for moderate to shallow sources; whereas, the BooreAtkinson relation [27] might be applied for a shallow reverse fault, such that located at the back arc of Lombok Island [28].

Deep megathrust could generate deep earthquake events that may develop low ground accelerations. However, since various sources could generate multiple seismic events, this could create uncertainties in seismic hazard analysis. A logic tree method was, therefore, applied in probabilistic seismic hazard analyses according to [29]; as can be seen in Figure 4, all aspects of earthquakes were weighted to reduce uncertainties in seismic hazard analysis.

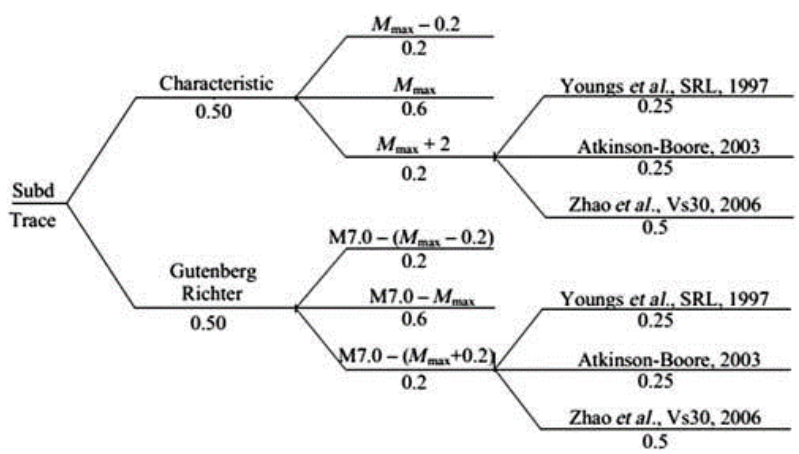

(a)
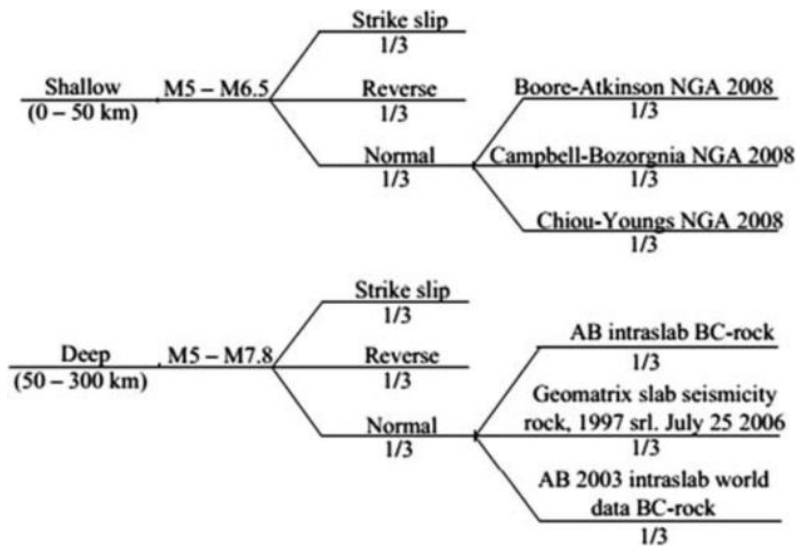

(b)

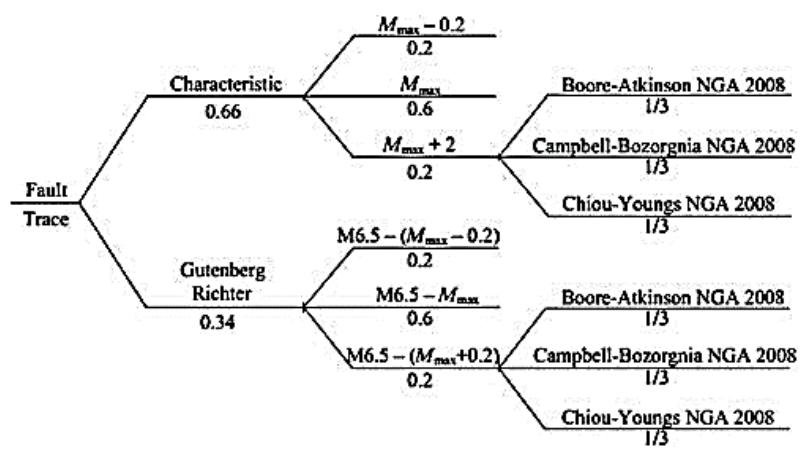

(c)

Figure 4: Logic tree of probabilistic seismic hazard analysis for general earthquake events in Indonesia: a) subduction sources; b) shallow and deep background sources; c) fault sources [29]. 


\section{RESULTS AND DISCUSSION}

\section{Data Set}

Earthquake data were declustered to separate the data set into independent (mainshock) and dependent (aftershock and foreshock) according to Gardner and Knopoff [30]. The declustering process was conducted using ZMAP software developed by Wiemer [31]. The process of more than 5000 data resulted in 2160 mainshocks of $\mathrm{Mw}>3.0$.

According to $[4,5]$, these earthquake events occurred at four tectonic zones: subduction zone, fore-arc basin (Lombok Basin), magmatic-arc, and back arc basin (Bali Basin) [4], (Figure 5). The events at the back arc and fore arc basins were dominantly shallow, approximately $80 \%$ occurred at the depths of less than $100 \mathrm{~km}$, and only $20 \%$ of total events occurred at the depths of 100-300 km. Few deep earthquakes occurred at the depths of $>300 \mathrm{~km}$, and the deepest event was at the depth of $400 \mathrm{~km}$ [32].

During the period of 1922-2018, about 641 mainshocks of Mw>4.5 might cause significant impacts to Lombok and surrounding islands. Interestingly, there were some events of Mw7.0 in three periodical occurrences: 1922-1927, 1978-1979, and 2009-2018; and the last two occurred at a similar location around the Bayan-Pemenang area of the North Lombok District with no intact building remaining, as shown in Figure 6 .

The repetitive occurrences have been previously predicted [34], which indicated strong earthquake events of Mw6.5 might apparently occur in every forty years-period; while, shorter repetitive events of Mw6.0 might occur in every twenty yearsperiod. A series of strong earthquakes also occurred along the particular FT in 1815, 1818 and 1820, as reported by [35]

\section{Seismic Sources}

As shown earlier in Figure 2, Lombok Island located between the Sunda Arc and Banda Arc. The island is projected to have a high seismicity index, as shown through previous estimations $[34,36]$, and this means that it is important to evaluate its current seismic conditions after the occurrence of earthquakes in 2018 .

Three main seismic sources were applied to analyze the seismicity of Lombok and surrounding islands: subduction, background, and back arc shallow fault [21]. Background sources were particularly divided into five depth intervals [29]. Then, the Gutenberg-Richter $a$ - and $b$-parameters were estimated using Equation 1. Results are depicted in Figure 7, and tabulated in Table 1 for every earthquake source.

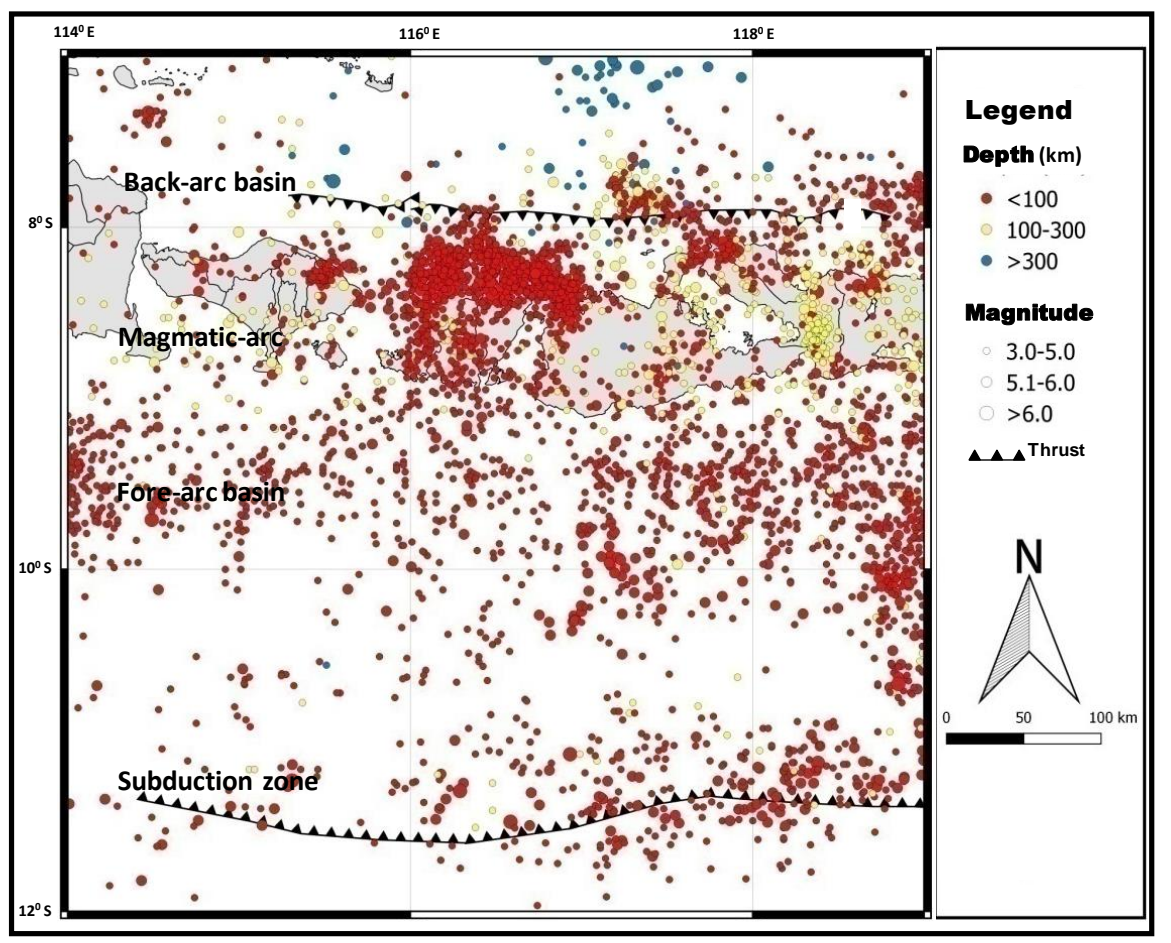

Figure 5: Seismicity map of 2160 mainshock data of Mw>3.0 during the period of 1922-2018, distributed around Lombok Island within four tectonic zones: subduction zone, fore arc basin, magmatic arc and back arc basin [4, 5].
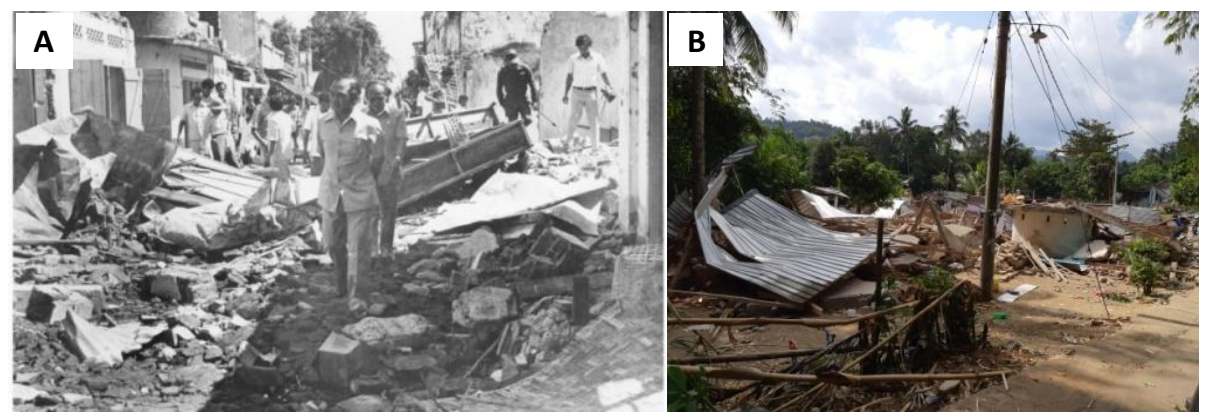

Figure 6: Ruined buildings and homes due to Lombok earthquakes at the North Lombok District: A) in 1979 [33], B) in 2018. 


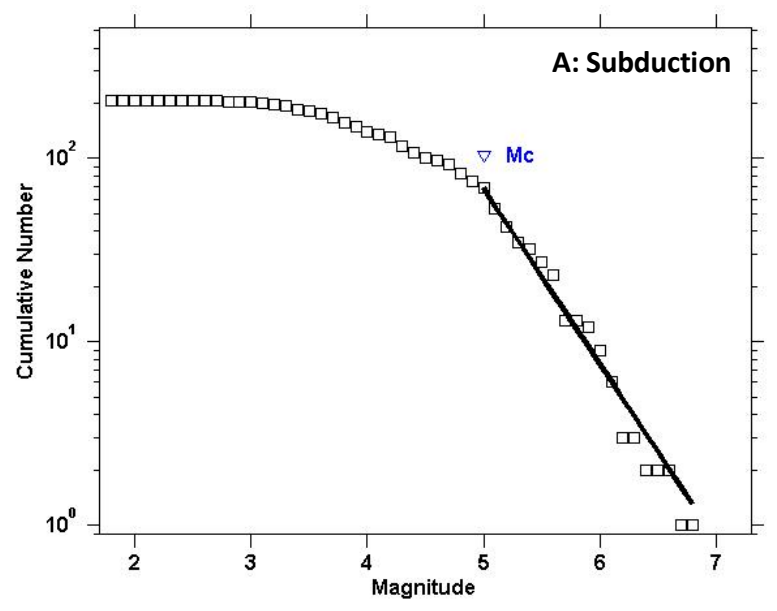

Maximum Likelihood Solution

b-value $=0.956+1-0.1$, a value $=6.62$, a value $($ annual $)=4.88$ Magnitude of Completeness $=5$

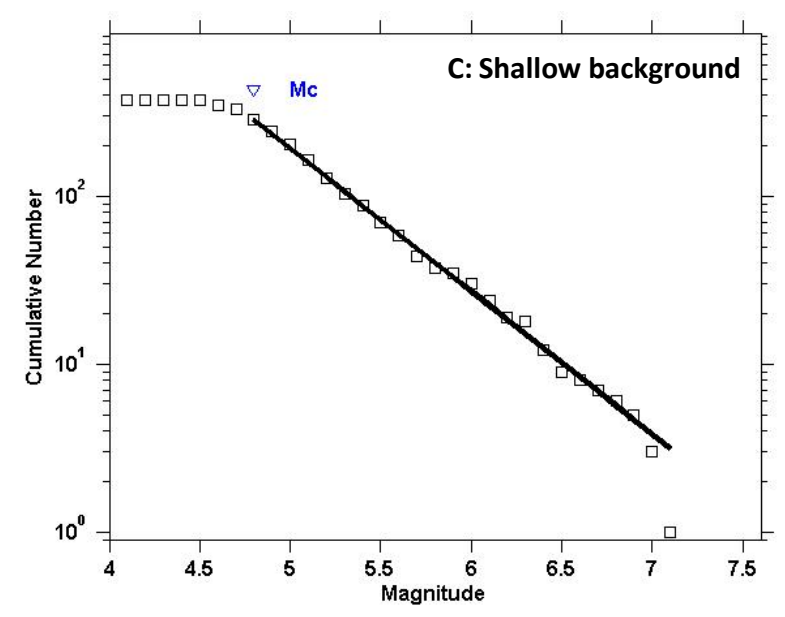

Maximum Likelihood Solution

b-value $=0.85+/-0.05$, a value $=6.54$, a value $($ annual $)=4.55$ Magnitude of Completeness $=4.8$

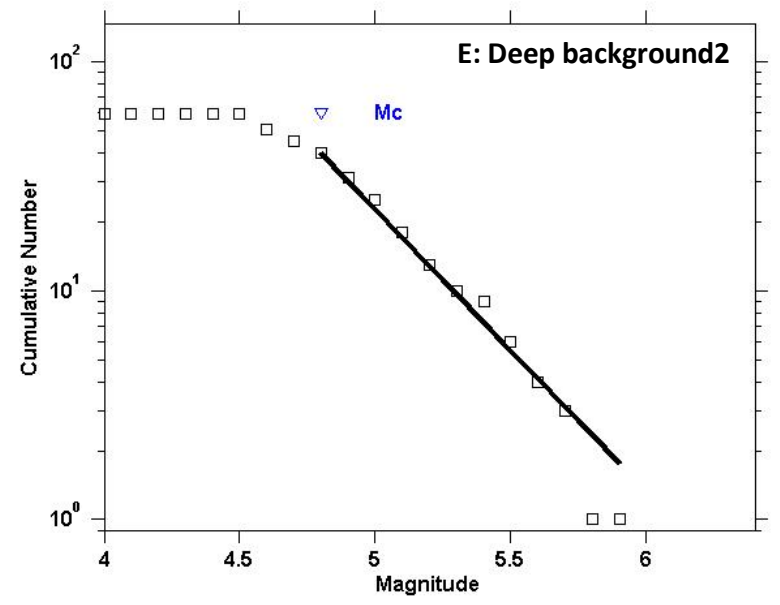

Maximum Likelihood Solution

b-value $=1.23+i-0.2$, a value $=7.52$, a value $($ annual $)=5.79$ Magnitude of Completeness $=4.8$

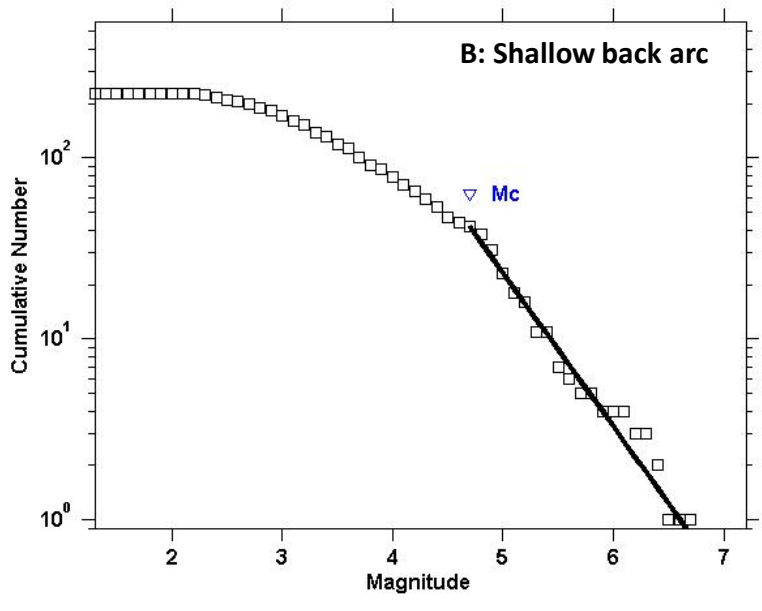

Maximum Likelihood Solution

b-value $=0.848+j-0.1$, a value $=5.61$, a value $($ annual $)=3.77$ Magnitude of Completeness $=4.7$

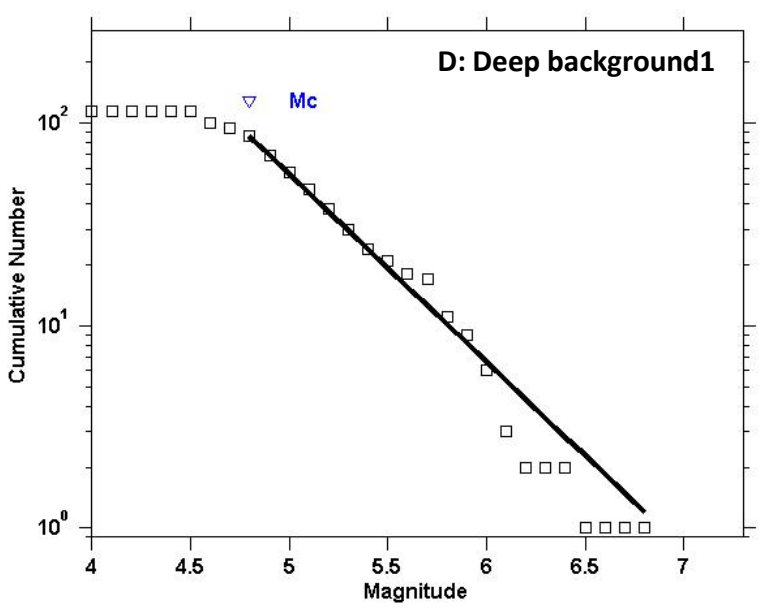

Maximum Likelihood Solution

b-value $=0.927+\{-0.09$, a value $=6.38$, a value (annual $)=4.64$ Magnitude of Completeness $=4.8$

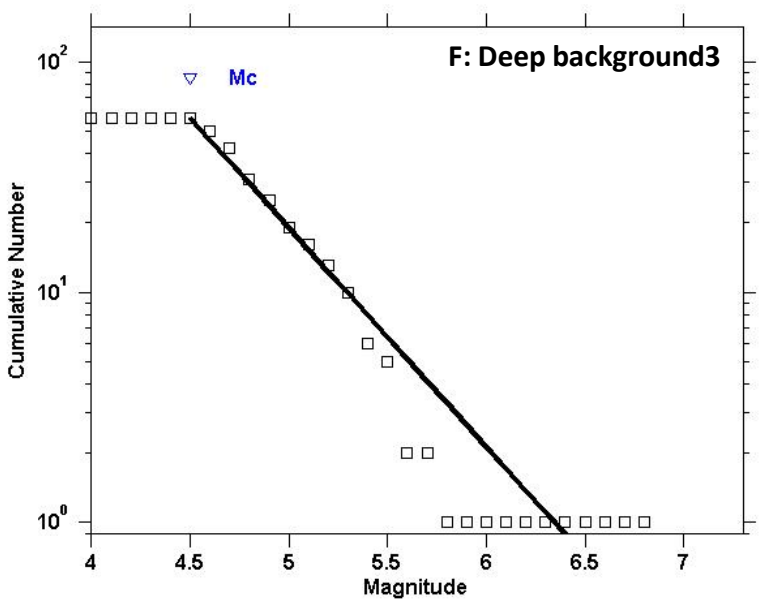

Maximum Likelihood Solution

b-value $=0.95+j-0.1$, a value $=6.03$, a value (annual $)=4.28$ Magnitude of Completeness $=4.5$

Figure 7: The Gutenberg-Richter relation for sources: A) subduction $(<100 \mathrm{~km})$; B) shallow back arc thrust (<50 km); C) shallow background (<50 km); D) deep background1 (50-100km); E) deep background2 (100-150 km); 


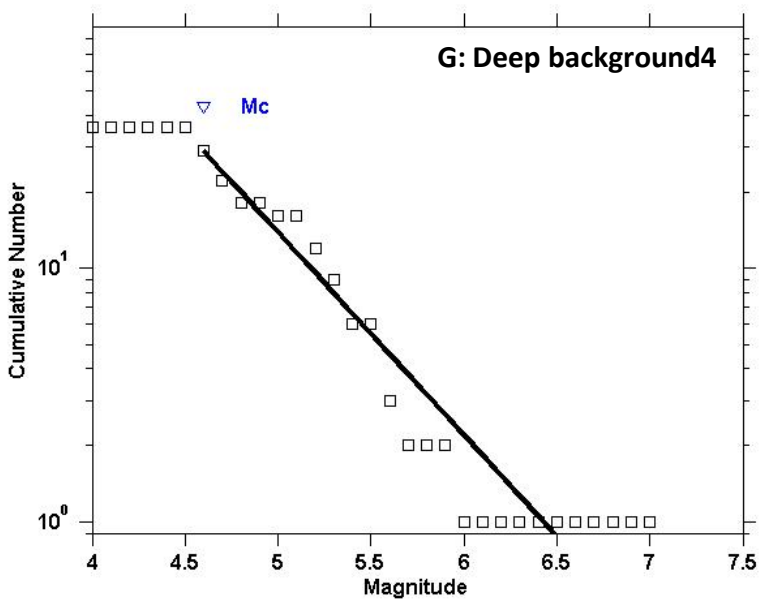

Maximum Likelihood Solution

b-value $=0.8+\zeta-0.1$, a value $=5.14$, a value (annual $)=3.47$

Magnitude of Completeness $=4.6$

Figure 7 (Continued): The Gutenberg-Richter relation for sources: G) deep background4 (>200 km).

Table 1: The a- and b-values of the Gutenberg-Richter relation for seven sources of Lombok and surrounding islands.

\begin{tabular}{lccc}
\hline \multicolumn{1}{c}{ Source } & $\boldsymbol{a}$-value & $\boldsymbol{b}$-value & Mc \\
\hline Subduction & 6.62 & -0.96 & 5.0 \\
Shallow back arc thrust & 5.61 & -0.85 & 4.7 \\
Shallow background & 6.54 & -0.85 & 4.8 \\
Deep background1 & 6.38 & -0.93 & 4.8 \\
Deep background2 & 7.52 & -1.23 & 4.8 \\
Deep background3 & 6.03 & -0.95 & 4.5 \\
Deep background4 & 5.14 & -0.80 & 4.6
\end{tabular}

Subduction $(<100 \mathrm{~km})$; shallow back arc thrust $(<50 \mathrm{~km})$; shallow background (<50 km); deep background1 $(50-100 \mathrm{~km})$; deep bakground2 (100-150 km); deep background3 (150-200 km); deep background 4 (>200 km).

The $a$ - and $b$-values were 6.62 and -0.96 for the subduction sources, 5.61 and -0.85 for the shallow back arc thrust sources, with the Mcs of 5 and 4.7, respectively. The deep background4 sources, where earthquakes occurred at the fore-arc basin and magmatic arc zones, had the lowest $a$ - and $b$-values compared to other sources, which were 5.14 and -0.8 with the Mc of 4.6; whereas, the highest values were 7.52 and -1.23 with the Mc of 4.8 for the deep background 2 sources.

The background sources were dominant, but they tend to produce deep seismic events, which might consequently provide low impacts to the islands, in contrast to that from the shallow back arc thrust sources. These high seismicity indexes might be influenced by many processes [23], which could be fault heterogeneity [37], and micro-fracturing [38]. In the case of Lombok Island, particularly the back arc thrust sources, the thrust is not only a complex geological feature [39], but more importantly the shallow seismic sources [35] are simply too close to the island to the extent that one third of the island was destroyed within 8 weeks during July-September 2018 [36].

Generally, an area with a low $b$-value will be potentially to have a large magnitude earthquake compared to that with a high level $b$-value [40]. This is called temporal variations in $b$-values, and such potential could impose to damaging earthquakes [41, 42]. Many studies show that the $b$-value decreased before large earthquakes, and the decrease even occurred for several years before large earthquakes occurred [40, 43]. In fact, such that low $b$-values for shallow back arc thrust source were relatively lower than that for other sources, where mostly earthquakes with Mw over 6.5 occurred in the back arc zone of Lombok Island.

\section{Ground Motion Relation Applicable to Lombok Island}

A number of empirical attenuation equations have been developed by many researchers for different tectonic characteristics [25]. Two of them, Joyner-Boore [26] and Boore-Atkinson [27], have already been recognised to be suitable for the tectonic characteristics of Indonesia [21], particularly Lombok Island [28].

According to [44], however, earthquake ground motions are influenced by source, propagation, and site effects. The JoynerBoore equation indicates the influence of magnitude, distance, and site characterization, which was suitable for Lombok Island [28]. However, the shallow FT was observed to have a dominant influence on current seismic occurrences [12], and the closed distance of the FT to the island seemed to play a crucial role in the ground motion for the island; accordingly, the BooreAtkinson relation was appropriate for these tectonic sources [21]. Meanwhile, the Youngs et al. equation [45] might be utilised for the deep subduction sources of the island.

Boore [46], however, suggested the use of a ground motion equation to provide reasonable predictions due to poor data, but, the equation is able predict engineering impacts on buildings. For the particular single event of Mw7.0 in $5^{\text {th }}$ August 2018 occurred at the back arc, the Boore-Atkinson was then employed to calculate the PGA values for several most affected locations in Lombok Island [1, 18, 47], including Bayan, Tanjung, Pemenang and Mangsit in the North Lombok District; Jeringo and Guntur Macan in the West Lombok District; and Mataram City; also, for the least affected Lombok Airport. Results can be seen in Table 2, compared with that observed by Ardian et al. [48] and the USGS [18].

Table 2 shows that Bayan, the epicentre of the $5^{\text {th }}$ August 2018 earthquake, had the highest PGA value of $1.49 \mathrm{~g}$; while, other ruined locations, except the Lombok Airport, had PGA values over $0.5 \mathrm{~g}$. The Joyner-Boore hypocenter distance (R $\mathrm{R}_{\mathrm{JB}}$ ) seems to influence the calculated PGA, a location with a higher $\mathrm{R}_{\mathrm{JB}}$ tends to have a lower PGA, as shown in Figure 8. 
Table 2: PGA values for a single event of earthquake occurred in $5^{\text {th }}$ August 2018 at various locations in Lombok

Island. Comparison given between current and official analysis data reported by Ardian et al. [48] and the USGS [18] for the nearest recorder station calculated after the event, showing different values for each location.

\begin{tabular}{lccc}
\hline \multicolumn{1}{c}{ Location / Station } & PGA1 (g) & $\begin{array}{c}\text { PGA2 (g) } \\
{[\mathbf{4 8}]}\end{array}$ & $\begin{array}{c}\text { PGA3 (g) } \\
{[\mathbf{1 8}]}\end{array}$ \\
\hline Bayan & 1.49 & 1.07 & - \\
Tanjung/STA30 & 0.74 & 0.75 & 0.79 \\
Pemenang/STA33 & 0.63 & 0.57 & 0.63 \\
Mangsit/STA29 & 0.54 & 0.45 & 0.68 \\
Jeringo/STA32 & 0.58 & 0.40 & 0.33 \\
Guntur Macan & 0.58 & 0.40 & - \\
Mataram/STA31 & 0.53 & 0.22 & 0.55 \\
Lombok Airport/STA34 & 0.47 & 0.06 & 0.06 \\
\hline STA = recorder station, for example STA30 located at Tanjung in the \\
\multicolumn{3}{c}{ North Lombok District [18]. }
\end{tabular}

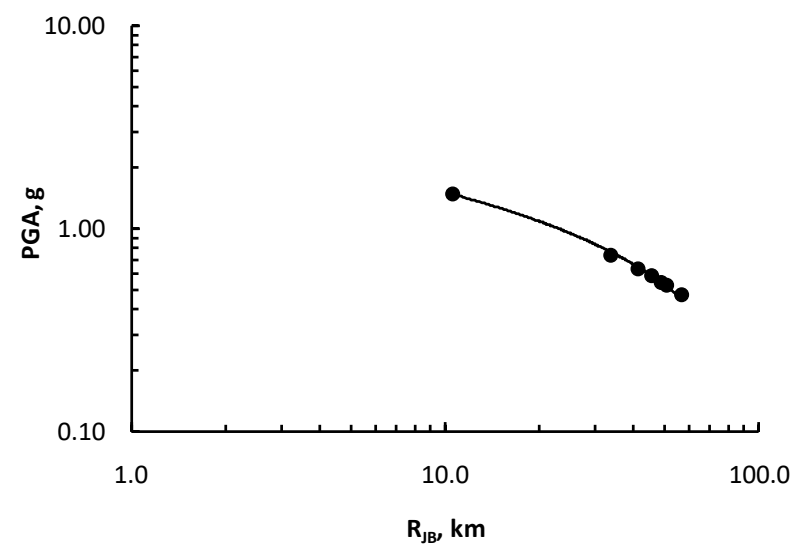

Figure 8: Plotted data between hypocenter distance $\left(\boldsymbol{R}_{J B}\right)$ and PGA value for eight locations identified in Table 2; where Bayan had an $R_{J B}$ of $31 \mathrm{~km}$, while the Lombok Airport had an $R_{J B}$ of $57 \mathrm{~km}$, with PGA values of $1.49 \mathrm{~g}$ and $0.47 \mathrm{~g}$, respectively.

The $\mathrm{R}_{\mathrm{JB}}$ values for Bayan and the Lombok Airport were 31 and $57 \mathrm{~km}$, respectively; but, a PGA of $0.47 \mathrm{~g}$ for the airport was probably overvalued, considering the airport is located at the magmatic-arc; while, using Youngs et al. [45], the PGA for this particular location was $0.12 \mathrm{~g}$, compared with that of the Station 34 of the USGS and BMKG was only $0.06 \mathrm{~g}$. This indicates that the influence of the R Rв is possibly limited at long distances and deep crustal sources [49].

PGA estimations have been previously conducted before the earthquake events in 2018 [15, 17, 50]. Some previous PGA values might still be relevant; for example, for those of megathrust, but, those of back arc thrust seismic sources could be undervalued regarding the current tectonic conditions of Lombok Island. Thus, the use of seismic parameters for future civil engineering design should represent current seismic conditions, as suggested for infrastructures in Mataram City [47], and the North Lombok District [51].

\section{PSHA for Lombok and Surrounding Islands}

Probability seismic hazard analysis (PSHA) was adopted to estimate properly the devastating earthquake occurrences around Lombok Island. The purpose of the analysis is to evaluate the hazard of seismic ground motion at a site by considering all possible earthquakes within the area, estimating the associated shaking at the site, and calculating the probabilities of these occurrences [52]. The analysis should represent the most resilient means to calculate seismic load parameters, carefully chosen for seismic designs [53].

The analysis certainly involves a lot of uncertainty and variability [54], however, three important steps in the analysis: seismic source, magnitude distribution, and attenuation function, can be derived to gain the objective of the analysis. Seismic sources, magnitude distributions and the application of three ground motion prediction equations (GMPEs) for estimating the PGA values for Lombok Island have been discussed earlier.

As Lombok and surrounding islands are divided into four tectonic zones, as shown in Figure 5, the Boore-Atkinson equation [27] provided more tectonic condition effects of the shallow FT, while the Youngs et al. equation [45] was suitable for deep subduction sources, and the Atkinson-Boore equation [55] was suitable for deep background earthquakes. These three and other suggested GMPEs [56-58] in the logic tree method in Figure 4 were, therefore, applied in the PSHA for Lombok and surrounding islands. Although, the more updated GMPEs for shallow fault sources were applied by Irsyam et al. [15], the results might not be significantly different with that of the earlier version GMPEs [59], due to uncertainties in ground motion variation are incorporated into the use of logic trees [60].

The PSHA might apply two methods based on the period of observation and time. Meanwhile, it was hard to apply the timedependent method as used by Gerstenberger et al. [61] in Lombok and surrounding islands due to the lack of complete data available in the early period of observation. However, both methods might be applicable for some parts of Indonesia, where data are sufficiently accurate to quantify each source for time and data production [15]

The current PSHA used the declustered data of $\mathrm{Mw}>4.5$ for the event period of 1922-2018, to determine parameters for peak ground acceleration of bedrock (PGA), spectral acceleration at $\mathrm{T}=0.2$ second $(\mathrm{Ss})$, and spectral acceleration at $\mathrm{T}=1.0$ second $\left(S_{1}\right)$ for the applied exceedance probability of $2 \%$ in 50 years. All results are mapped in Figures 9, 10, and 11; while the PGA values (PGA1) for some cities around Nusa Tenggara and East Java are presented in Table 3, compared with the PGA2 given by Irsyam et al. [15].

Table 3: PGA values for various cities in the Nusa Tenggara islands and East Java after earthquakes in 2018 for the applied exceedance probability of $2 \%$ in 50 years.

\begin{tabular}{lcc}
\hline Location & PGA1 (g) & PGA2 [15] (g) \\
\hline Bayan (Lombok) & 0.75 & 0.6 \\
Mataram (Lombok) & 0.65 & 0.5 \\
Sumbawa Besar (Sumbawa) & 0.6 & 0.5 \\
Bima (Sumbawa) & 0.55 & 0.6 \\
Labuhan Bajo (Flores) & 0.6 & 0.5 \\
Waingapu (Sumba) & 0.55 & 0.5 \\
Maumere (Flores) & 0.5 & 0.5 \\
Denpasar (Bali) & 0.5 & 0.5 \\
Banyuwangi (East Java) & 0.4 & 0.4 \\
\hline
\end{tabular}




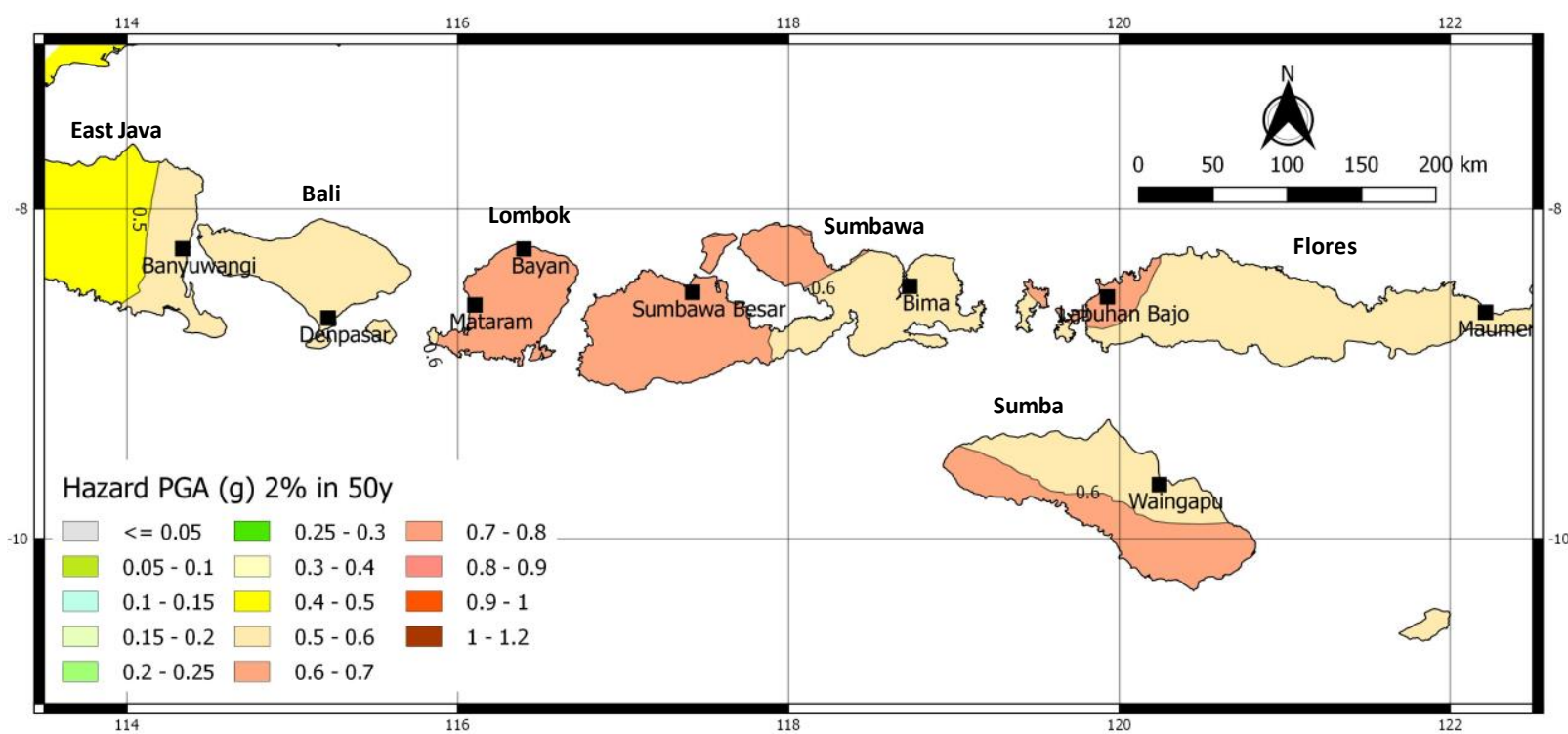

Figure 9: Map of peak ground acceleration on bedrock with an exceedance probability of $2 \%$ in 50 years for Lombok Island and surrounding islands.

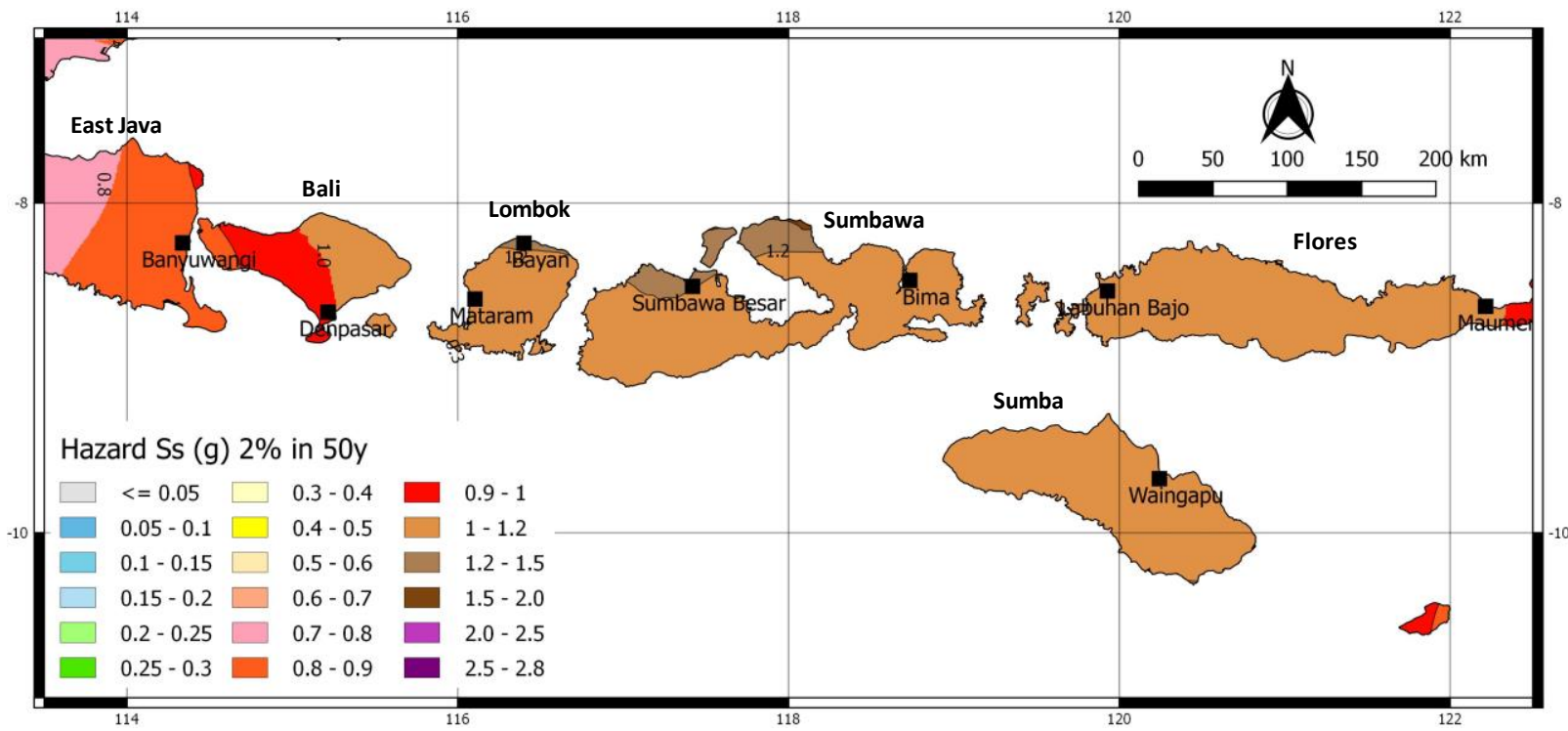

Figure 10: Map of spectral acceleration Ss $(T=0.2 \mathrm{~s})$ on bedrock with an exceedance probability of $2 \%$ in 50 years for Lombok Island and surrounding islands.

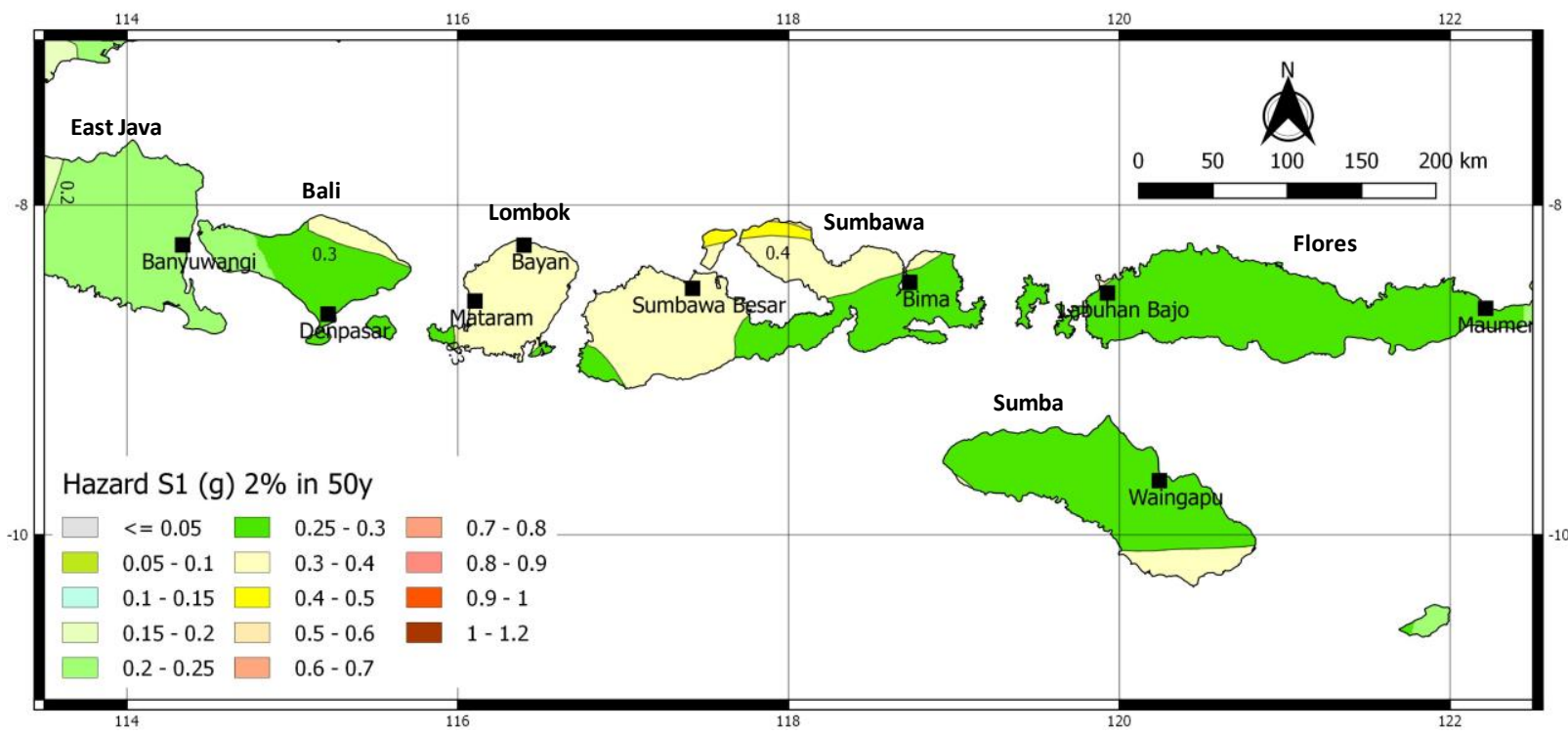

Figure 11: Map of spectral acceleration $S_{1}(T=1.0$ s) on bedrock with an exceedance probability of $2 \%$ in 50 years for Lombok Island and surrounding islands. 
Figure 9 shows that the current PGA values of bedrock were 0.6-0.7 $\mathrm{g}$ for the most part of Lombok and some part of Sumbawa Islands. The highest PGA value was $0.75 \mathrm{~g}$ for Bayan, where was the epicentre of the $5^{\text {th }}$ August 2018 event. Meanwhile, the PGA values of bedrock for other area were 0.5$0.6 \mathrm{~g}$, and some parts of East Java had the values of $0.4-0.5 \mathrm{~g}$.

The current PGA values of bedrock increased by approximately $6 \%$ compared to those estimated previously by Irsyam et al. [15] and the SNI 1726:2019 [17], as shown in Figure 12. The increase might be associated with the fact that the data used in the previous estimations were dated to 2016. In addition, the current applied maximum magnitudes were 8.0 for the shallow back arc thrust sources, and 9.0 for the subduction-megathrust sources; whereas, those of the 2017 models were 7.8 and 8.1, respectively $[15,62]$. Moreover, the complexity of the back arc thrust lead to the use of the $M_{\max }$ of Mw8.5 [63] and Mw8.4 $[35,63]$ to reflect locking depths of $30 \mathrm{~km}$ of the FT [64]. A high $M_{\max }$ of approaching Mw9.0 may be hard to occur for the FT, although, a lot of uncertainty may still apply.
The differences in the PGA values also indicate the variations in seismic conditions with the back arc up-thrusting having the possibility of being more dominant in Lombok Island, as indicated in the increased maximum magnitude [59]. Furthermore, the differences in seismic sources could differentiate the PGA values between Lombok Island, Bali Island and East Java, with those of the last two locations were dominated by background sources [12, 29]. Previous research $[7,8,39,65]$ showed the complexity of the FT, and the current seismic hazard analysis discovered its significant role in the seismic conditions of Lombok and surrounding islands.

Figure 10 shows that the most Lombok Island area had the Ss values in the range of $1.0-1.2 \mathrm{~g}$, while the northern part had the values higher than $1.2 \mathrm{~g}$. Similar values were estimated for the northern part of Sumbawa Island, where also dominated by the back arc sources. These values were, however, higher than $0.9-$ $1.2 \mathrm{~g}$ previously estimated in Figure $13[15,17]$. One important reason could be that the quantity of big shocks and maximum magnitude increased [11].

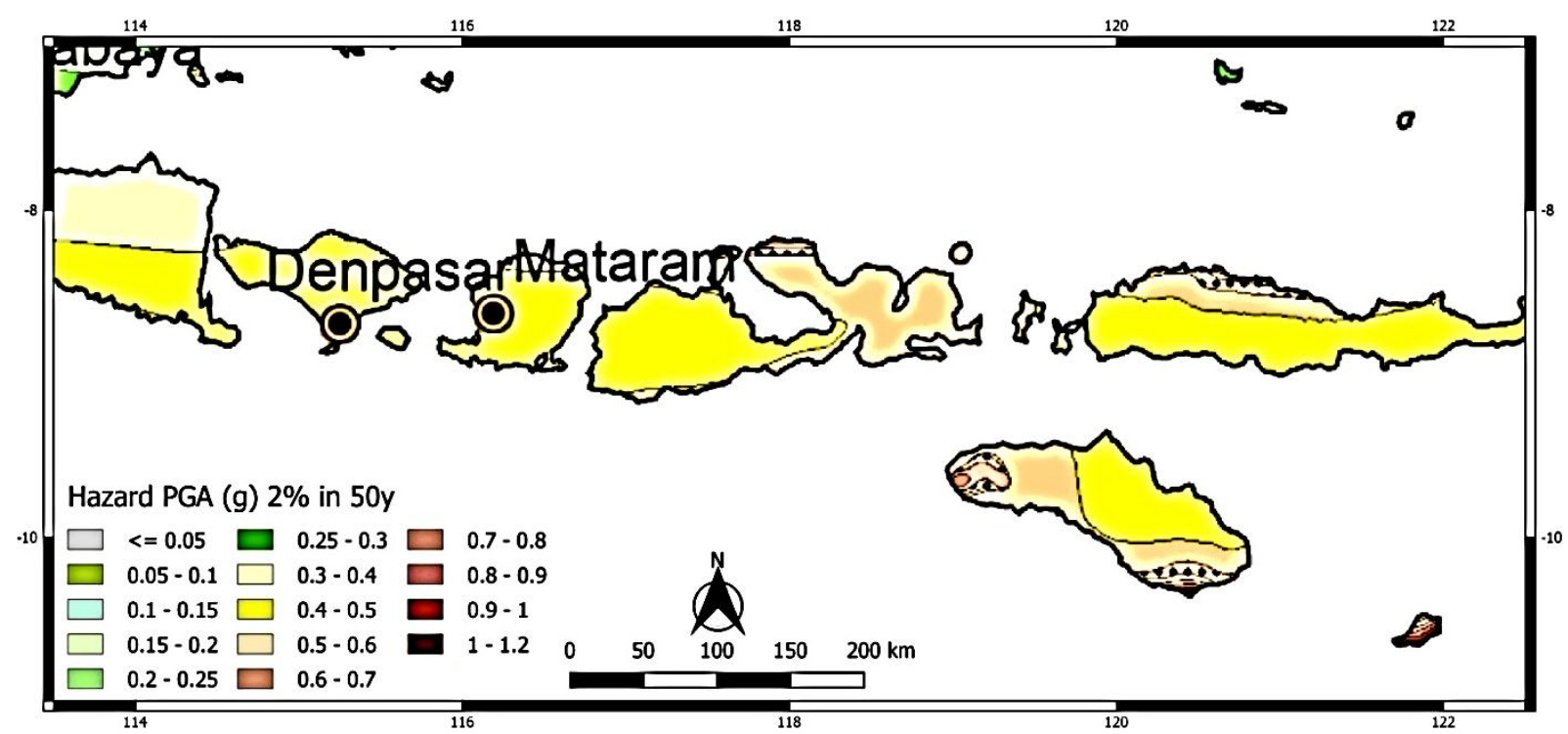

Figure 12: Map of peak ground acceleration on bedrock with an exceedance probability of $2 \%$ in 50 years for Lombok Island and surrounding islands, redrawn from Irsyam et al. [15].

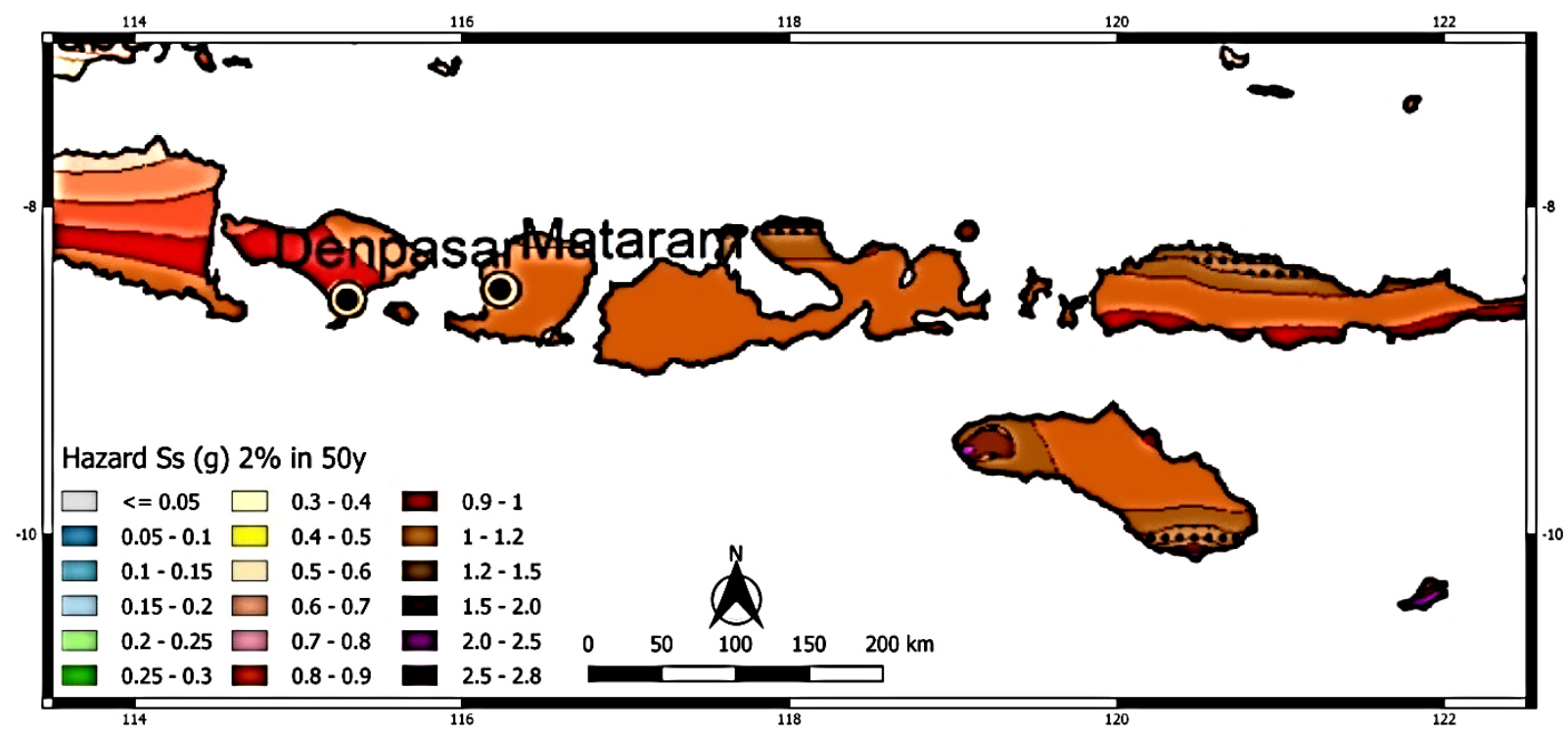

Figure 13: Map of spectral acceleration $S s(T=0.2$ s) on bedrock with an exceedance probability of $2 \%$ in 50 years for Lombok Island and surrounding islands, redrawn from Irsyam et al. [15]. 


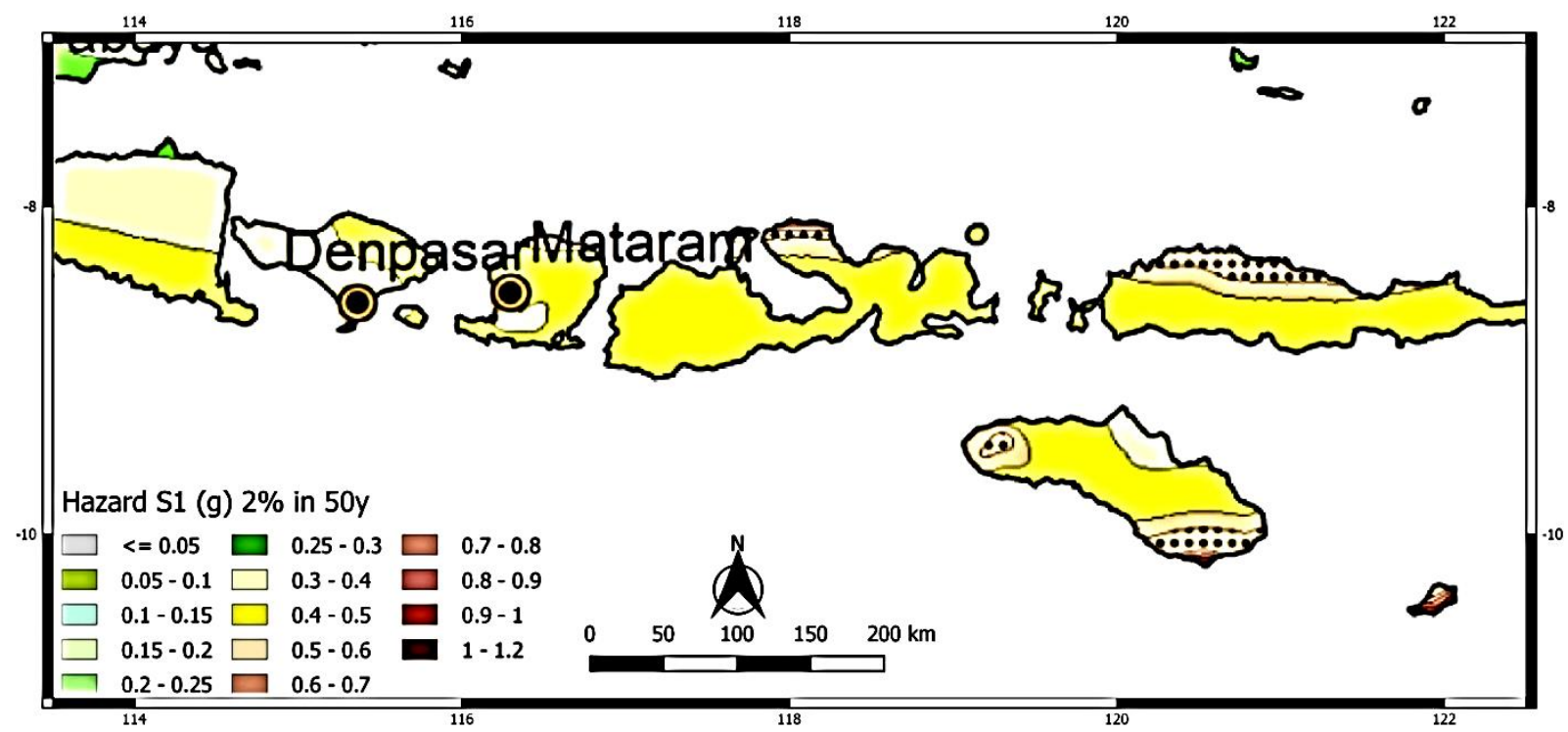

Figure 14: Map of spectral acceleration $S_{1}(T=1.0$ s) on bedrock with an exceedance probability of $2 \%$ in 50 years for Lombok Island and surrounding islands, redrawn from Irsyam et al. [15].

The $S_{1}$ values in Figure 11 were, however, slightly lower than the previous values $[15,17]$. Particularly, the current $S_{1}$ values were $0.25-0.4 \mathrm{~g}$ compared to the previous 2017 models of 0.25 $0.6 \mathrm{~g}$ for Flores and Sumba Islands. Meanwhile, the values are generally found to be in a similar range of $0.25-0.6 \mathrm{~g}$ for Nusa Tenggara islands, as shown in Figure 14 [15]. This possibly indicates a non-linearity estimation of the $S_{1}$ attenuation relation; and fewer effects of the changes in earthquake sources on the value for bedrock. The shock amplification of the long period of $\mathrm{S}_{1}$ was, however, higher than that of $\mathrm{S}_{0}$ and $\mathrm{S}_{0}$

Probabilistic occurrences of earthquakes around Lombok Island are high within 50 years of an exceedance probability of $2 \%$. Earthquakes of Mw6.0 might occur within an average periodic time of 3.5 years; while that of Mw6.5 might occur within a periodic time of 10 years. These were shorter than previous estimations of 16-67 years [34]; but, still within the range of 212 years for Indonesia [66]. However, earthquakes with higher magnitudes of Mw6.5 may occur in a longer periodic time. When considering the last occurrence in $5^{\text {th }}$ August 2018 of Mw7.0, earthquakes occurred along the FT with such a magnitude might have a periodic time of reoccurrence of 40 years, which was also shorter than previous estimations of 54104 years [34].

Based on the last earthquake events, Lombok Island is very much vulnerable to seismic hazards. For instance, Mataram City had a high seismic intensity index of MMI VIII [67], which means that the city is susceptible to severe damage in the case of earthquakes with a PGA of $0.65 \mathrm{~g}$, Ss of $1.15 \mathrm{~g}$, and $\mathrm{S}_{1}$ of $0.35 \mathrm{~g}$ occur within 50 years of an exceedance probability of $2 \%$ [12]. For a comparison, the City of Bima in Sumbawa Island also shows similar seismic conditions; but differs from the City of Kupang in Timor Island [68], where was dominated by subduction-megathrust sources. The PSHA parameters for Kupang were lower than those of Mataram and Bima. As consequences, probability analyses show that medium and weaker earthquakes have a bigger chance of reoccurrence in Lombok and surrounding islands, most probably within 5 years [69].

\section{CONCLUSIONS}

A series of Lombok earthquakes occurred in 2018 were triggered on the Flores Fault, located just at the back arc zone of Nusa Tenggara islands. The closeness of the complex tectonic structure to the islands, particularly Lombok, was found to play an important role in the seismicity of the region. An update to probabilistic hazard analysis, including recent seismicity, detailed tectonic background, and suitable ground motion prediction equations, showed an increase in of the seismic levels. There is an indication of higher values in PSHA parameters, such as PGA and Ss for bedrock; although, $S_{1}$ was found to be slightly lower than the estimate before the events. These increased values can be used to represent current seismic conditions, and are, therefore, applicable in future civil engineering design within the region.

\section{ACKNOWLEDGMENTS}

Authors acknowledge the BMKG, USGS and ISC for the use of their data sets. Authors also would like to thank the BMKG for their help in applying the USGS software for PSHA [70]. Finally, authors would like to appreciate the anonymous reviewers and editor in chief for useful comments to improve the article.

\section{REFERENCES}

1 Indonesian Agency for Meteorology, Climate and Geophysics (BMKG) (2019). https://repogempa.bmkg.go.id/repo new/

2 Indonesian Agency for Meteorology, Climate and Geophysics (BMKG) (2018). Press Release No: UM.505/3/D3/VIII/2018 (in Indonesian). https://www.facebook.com/InfoBMKG/posts/1015654833 9904931

3 Pramono S (2018). "Perencanaan Rekonstruksi Wilayah Lombok Berbasis Mitigasi Gempabumi". Indonesian Agency for Meteorology, Climate and Geophysics (BMKG) (in Indonesian).

https://cdn.bmkg.go.id/web/Artikel_20181002115022_u1d puf_-Perencanaan-Rekontruksi-Wilayah-LombokBerbasis-Mitigasi-Gempabumi.pdf

4 Hamilton W (1974). "Earthquake Map of Indonesian Region”. USGS, Folio of the Indonesia Region, Map 1-875C, Scale 1:5000000.

5 Hamilton W (1979). "Tectonics of the Indonesian Region". US Geological Survey Professional Paper 1078, 345 pp.

6 Bock Y, Prawirodirdjo L, Genrich JF, Stevens CW, McCaffrey R, Subarya C, Puntodewo SSO and Calais E (2003). "Crustal Motion in Indonesia from Global Positioning System 
Measurements”. Journal of Geophysical Research, 108: 2367. https://doi.org/10.1029/2001JB000324

7 Koulali A, Susilo S, McClusky S, Meilano I, Cummins P, Tregoning P, Lister G, Efendi J, and Syafi'i MA (2016). "Crustal Strain Partitioning and the Associated Earthquake Hazard in the Eastern Sunda-Banda Arc". Geophysical Research Letters, 43: 1943-1949. https://doi.org/10.1002/2016GL067941

8 Pranantyo IR and Cummins PR (2019). "Multi-Data-Type Source Estimation for the 1992 Flores Earthquake and Tsunami'. Pure and Applied Geophysics. https://doi.org/10.1007/s00024-018-2078-4

9 Agustawijaya DS, Karyadi K, Krisnayanti BD and Sutanto S (2017). "Rare Earth Element Contents of the Lusi Mud: An Attempt to Identify the Environmental Origin of the Hot Mudflow in East Java - Indonesia". DeGruyter Open Geoscience, 9: 689-706. https://doi.org/10.1515/geo-2017-0052

10 Katili JA (1989). "Evolution of the Southeast Asian Arc Complex". Geologi Indonesia, 12(1): 113-143.

11 Verstappen MT (2010). "Indonesian Landforms and Plate Tectonics". Indonesian Journal on Geoscience, 5(3): $197-$ 207. https://doi.org/10.17014/ijog.v5i3.103

12 Nugraha AD, Kusnandar R, Puspito NT, Sakti AP and Yudistira T (2014). "Preliminary Results of Local Earthquake Tomography around Bali, Lombok, and Sumbawa Regions". AIP Conference Proceedings, 1658: 030019-1-030019-4. https://doi.org/10.1063/1.4915027

13 Setyono U, Gunawan I, Priyobudi et al. (2019). "Katalog Gempabumi Signifikan dan Merusak 1821-2018”. Pusat Gempabumi dan Tsunami, Badan Mateorologi, Klimatogi dan Geofisika, Jakarta (in Indonesian). https://cdn.bmkg.go.id/Web/Katalog-GempabumiSignifikan-dan-Merusak-1821-2018.pdf

14 Gusman AR, Tanioka Y, Matsumoto H and Iwasaki SI (2009). "Analysis of the Tsunami generated by the Great 1977 Sumba Earthquake that Occurred in Indonesia”. Bulletin of the Seismological Society of America, 99(4): 2169-2179. https://doi.org/10.1785/0120080324

15 Irsyam M, Widiyantoro S, Natawidjaja D, Meilano I, Rudyanto A, Hidayati S, Triyoso W, Hanifa N, Djarwadi D, Faizal L and Sunarjito S (2017). "Peta Sumber dan Bahaya Gempa Indonesia Tahun 2017”. Bandung. Pusat Gempa Nasioal (PUSGEN), Kementerian Pekerjaan Umum dan Perumahan Rakyat, 376 pp. (in Indonesian). https://www.pu.go.id/berita/view/15309/buku-petasumber-dan-bahaya-gempa-indonesia-tahun-2017

16 Hamilton W (1989). "Convergent-Plate Tectonics Viewed from the Indonesian Region”. Geology of Indonesia, 12(1): $35-88$

17 Badan Standardisasi Nasional (BSNI) (2019). "SNI 1726:2019 Tata Cara Perencanaan Ketahanan Gempa Untuk Struktur Bangunan Gedung dan Non Gedung”. 238 pp. (in Indonesian).

18 United State Geological Survey (USGS) https://earthquake.usgs.gov/earthquakes/search/

19 International Seismological Centre (ISC) (2019). http://www.isc.ac.uk/isc-ehb/search/catalogue/

20 Papazachos BC, Scordilis EM, Panagiotopoulos DG Papazachos CB and Karakaisis GF (2004). "Global Relations between Seismic Fault Parameters and Moment Magnitude of Earthquakes". Bulletin of the Geological Society of Greece, XXXVI: 1482-1489. https://doi.org/10.12681/bgsg.16538

21 Asrurifak M, Irsyam M, Budiono B, Triyoso W and Hendriyawan (2010). "Development of Spectral Hazard Map for Indonesia with a Return Period of 2500 Years
Using Probabilistic Method". Civil Engineering Dimension, 12(1): 52-62.

https://doi.org/10.9744/ced.12.1.52-62

22 Gutenberg B and Richter C (1949). "Seismicity of the Earth and Associated Phenomena". Princeton University Press, New Jersey, 273 pp.

23 Marzocchi W and Sandri L (2003). "Review and New Insights on the Estimation of the B-Value and Its Uncertainty". Analysis of Geophysics, 46(6): 1271-1282. https://doi.org/10.4401/ag-3472

24 Utsu T (1965). "A Method for Determining the Value of $b$ in a Formula $\log \mathrm{N}=\mathrm{a}-\mathrm{bM}$ Showing the Magnitude Frequency for Earthquakes". Geophysical Bulletin of the Hokkaido University, 13: 99-103.

25 Douglas J (2017). “Ground Motion Prediction Equations 1964-2017". Report, Department of Civil and Environmental Engineering, University of Strathclyde, Glasgow, United Kingdom, 595 pp.

26 Joyner WB and Boore DM (1988). "Measurement, Characterization, and Prediction of Strong Ground Motion". Proceedings of Earthquake Engineering \& Soil Dynamics, II: 43-102. Geotechnical Division, ASCE.

27 Boore DM and Atkinson GM (2008). "Ground-Motion Prediction Equations for the Average Horizontal Component of PGA, PGV, and 5\%-damped PSA at Spectral Periods between 0.01 s and 10.0 s". Earthquake Spectra, 24(1): 99-138. https://doi.org/10.1193/1.2830434

28 Agustawijaya DS, Sulistiyono H and Elhuda I (2018) "Determination of the Seismicity and Peak Ground Acceleration for Lombok Island: An Evaluation on Tectonic Setting”. MATEC Web of Conference, 195: 03018. https://doi.org/10.1051/matecconf/201819503018

29 Ashadi AL, Harmoko U, Yuliyanto G and Kaka SI (2015). "Probabilistic Seismic Hazard Analysis for Central Java Province, Indonesia”. Bulletin of the Seismological Society of America, 105(3): 1711-1720. https://doi.org/10.1785/0120140277

30 Gardner JK and Knopoff L (1974). "Is the Sequence of Earthquakes in Southern California, with Aftershocks Removed, Poissonian?". Bulletin of the Seismological Society of America, 64(5): 1363-1367.

31 Wiemer S (2001). "A Software Package to Analyze Seismicity: ZMAP”. Seismological Research Letters, 72(2): 373-382. https://doi.org/10.1785/gssrl.72.3.373

32 Jones ES, Hayes GP, Bernardino M, Dannemann FK, Furlong KP, Benz HM and Villaseñor A (2014). "Seismicity of the Earth 1900-2012 Java and Vicinity". USGS Open-File Report 2010-1083-N, 1 sheet, Scale 1:5000000. http://pubs.usgs.gov/of/2010/1083/n

33 Kompas. https://kompas.id/baca/video/2018/08/09/gempalombok-1979 (Accessed 9 August 2018)

34 Sunardi B, Istikomah M and Sulastri (2017). "Analisis Seismotektonik dan Periode Ulang Gempabumi Wilayah Nusa Tenggara Barat, Tahun 1973-2015”. Jurnal Riset Geofisika Indonesia, 1(1): 23-28 (in Indonesian).

35 Griffin J, Nguyen N, Cummins P and Cipta A (2019). "Historical Earthquakes of the Eastern Sunda Arc: Source Mechanisms and Intensity-Based Testing of Indonesia's National Seismic Hazard Assessment". Bulletin of the Seismological Society of America, 109(1): 43-65. https://doi.org/10.1785/0120180085

36 Pusat Studi Gempa Nasional (PUSGEN) (2018). “Kajian Rangkaian Gempa Lombok Provinsi Nusa Tenggara Barat". Kementerian Pekerjaan Umum dan Perumahan Rakyat, Jakarta, ISBN 978-602-5489-13-6, 196 pp.

37 Mogi K (1962). "Magnitude-Frequency Relationship for Elastic Shocks Accompanying Fractures of Various 
Materials and Some Related Problems in Earthquakes". Bulletin of the Earthquake Research Institute, University of Tokyo, 40: 831-883.

38 Scholz C (1968). "Microfractures, Aftershocks and Seismicity". Bulletin of the Seismological Society of America, 58(3): 1117-1130.

39 McCaffrey R and Nabelek J (1987). "Earthquakes, Gravity, and the Origin of the Bali Basin: An Example of a Nascent Continental Fold-and-Thrust Belt”. Journal of Geophysical Research, 92(B1): 441-460. https://doi.org/10.1029/JB092iB01p00441

40 Tsukakoshi Y and Shimazaki K (2008). "Decreased Bvalue prior to the M 6.2 Northern Miyagi, Japan, Earthquake of 26 July 2003". Earth, Planets and Space, 60: 915-924. https://doi.org/10.1186/BF03352847

41 Shi Y and Bolt B (1982). "The Standard Error of the Magnitude-Frequency B Value". Bulletin of the Seismological Society of America, 72(5): 1677-1687.

42 Gulia L and Wiemer S (2019). "Real-Time Discrimination of Earthquake Foreshocks and Aftershocks". Nature, 574(7777): 193-199. https://doi.org/10.1038/s41586-019-1606-4

43 Okal A and Romanowicz BA (1994). "On the Variation of b-Values with Earthquake Size". Physics of the Earth and Planetary Interiors, 87: 55-76. https://doi.org/10.1016/0031-9201(94)90021-3

44 Hadley D, Helmberger D and Orcutt JA (1982). "Peak Acceleration Scaling Studies". Bulletin of the Seismological Society of America, 72(3): 959-979.

45 Youngs RR, Chiou SJ, Silva WJ and Humphrey JR (1997). "Strong Ground Motion Attenuation Relationships for Subduction Zone Earthquakes". Seismological Research Letters, 68: 58-73. https://doi.org/10.1785/gssrl.68.1.58

46 Boore D (2015). "Ground Motion Prediction Equations: Past, Present, and Future". The 2014 William B. Joyner Lecture, the SMIP15 Meeting, Davis, California, 22 October 2015, 93 pp.

47 Kencanawati NN, Agustawijaya DS and Taruna RM (2020). "An Investigation of Building Seismic Design Parameters in Mataram City Using Lombok Earthquake 2018 Ground Motion". Journal of Engineering and Technological Sciences, 52(5): 651-664 https://doi.org/10.5614/j.eng.technol.sci.2020.52.5.4

48 Ardian Y, Santoso E, Kaluku A, Dawwam F, Sakti AP, Pramono S and Permana D (2018). "Ulasan Guncangan Tanah Akibat Gempa Lombok Timur 05 Agustus 2018". BMKG, 21 pp (in Indonesian).

49 Douglas J and Boore DM (2018). "Peak Ground Accelerations from Large (M7.2) Shallow Crustal Earthquakes: A Comparison with Predictions from Eight Recent Ground-Motion Models". Bulletin of Earthquake Engineering, 16: 1-21. https://doi.org/10.1007/s10518-017-0194-7

50 Indonesian Ministry for Public Work and Homes (PUSKIM) (2011). "Desain Spectra Indonesia". Pusat Penelitian dan Pengembangan, Kementerian Pekerjaan Umum (in Indonesian). https://puskim.pu.go.id/Aplikasi/desain spektra indonesia _2011/ (Accessed 27 July 2019)

51 Agustawijaya DS, Sulistyowati T, Layli BA and Agustawijaya AR (2019). "The Ground Deformation of the Luk Barat Bridge after Lombok Earthquakes 2018”. IOP Conference Series: Earth and Environmental Science, 389: 012051. https://doi.org/10.1088/1755-1315/389/1/012051

52 National Research Council (NRC) (1988). "Probabilistic Seismic Hazard Analysis". The National Academies Press,
Washington DC, $111 \mathrm{pp}$. https://doi.org/10.17226/19108

53 Grunthal G, Stromeyer D, Bosse C, Cotton F and Bindi D (2018). "The Probabilistic Seismic Hazard Assessment of Germany-Version 2016, Considering The Range of Epistemic Uncertainties and Aleatory Variability". Bulletin of Earthquake Engineering, 16: 4339-4395. https://doi.org/10.1007/s10518-018-0315-y

54 Baker WJ (2008). “An Introduction to Probabilistic Seismic Hazard Analysis, Version 1.3", 72 pp.

55 Atkinson GM and Boore DM (2003). "Empirical Ground Motion Relations for Subduction Zone Earthquakes and Their Application to Cascadia and Other Regions". Bulletin of the Seismological Society of America, 93: 1703-1729. https://doi.org/10.1785/0120020156

56 Zhao JX, Zhang J, Asano A, Ohno Y, Ouchi T, Takahashi T, Ogawa H, Irikura K, Thio H and Somerville P (2006). "Attenuation Relations of Strong Ground Motion in Japan using Site Classification Based on Predominant Period". Bulletin of the Seismological Society of America, 96: 898913. https://doi.org/10.1785/0120050122

57 Campbell KW and Bozorgnia Y (2008). "NGA Ground Motion Model for the Geometric Mean Horizontal Component of PGA, PGV, PGD and 5\% Damped Linear Elastic Response Spectra for Periods Ranging from 0.01 to 10 s". Earthquake Spectra, 24(1): 139-171. https://doi.org/10.1193/1.2857546

58 Chiou B and Youngs R (2008). "An NGA Model for the Average Horizontal Component of Peak Ground Motion and Response Spectra". Earthquake Spectra, 24(1): 173215. https://doi.org/10.1193/1.2894832

59 Taruna RM (2019). "Intensitas Kegempaan Kota Mataram Berdasarkan Data Gempabumi Tahun 1922-2018". Masters Thesis, University of Mataram, $82 \mathrm{pp}$ (in Indonesian).

60 McGuire RK (2004). "Seismic Hazard and Risk Analysis". Earthquake Engineering Research Institute, MNO-10, Oakland, CA, $221 \mathrm{pp}$.

61 Gerstenberger MC, Rhoades DA and McVerry GH (2016). "A Hybrid Time-Dependent Probabilistic Seismic Hazard Model for Canterbury, New Zealand". Seismological Research Letters, 87(6): 1311-1318. https://doi.org/10.1785/0220160084

62 Horspool N, Pranantyo I, Griffin J, Latief H, Natawidjaja DH, Kongko W, Cipta A, Bustaman B, Anugrah SD and Thio HK (2014). "A Probabilistic Tsunami Hazard Assessment for Indonesia". Natural Hazards and Earth System Science, 14: 3105-3122. https://doi.org/10.5194/nhess-14-3105-2014

63 Nguyen N, Griffin J, Cipta A and Cummins PR (2015). "Indonesia's Historical Earthquakes: Modelled Examples for Improving the National Hazard Map". Geoscience Australia, Record 2015/23, Canberra. https://dx.doi.org/10.11636/Record.2015.023

64 Griffin J and Davies G (2018). "Earthquake Sources of the Australian Plate Margin: Revised Models for the 2018 National Tsunami and Earthquake Hazard Assessments". Geoscience Australia, Record 2018/31, Canberra. http://dx.doi.org/10.11636/Record.2018.031

65 Zubaidah T, Korte M, Mandea M and Hamoudi M (2014). "New Insights into Regional Tectonics of the Sunda-Banda Arcs Region from Integrated Magnetic and Gravity Modeling". Journal of Asian Earth Science, 80: 172-184. https://doi.org/10.1016/j.jseaes.2013.11.013

66 Rohadi S (2009). "Studi Seismotektonik sebagai Indikator Potensi Gempabumi di Wilayah Indonesia". Jurnal Meteorologi dan Geofisika, 10(2): 111-120 (in 
Indonesian). http://dx.doi.org/10.31172/jmg.v10i2.40

67 Worden CB, Gerstenberger MC, Rhoades DA and Wald D J (2012). "Probabilistic Relationships between Ground Motion Parameters and Modified Mercalli Intensity in California". Bulletin of the Seismological Society of America, 102(1): 204 221. https://doi.org/10.1785/0120110156

68 Sina DT (2011). "Evaluasi Bahaya Gempa (Seismic Hazard) dengan Menggunakan Metode Point Source dan Penentuan Respons Spektra Desain Kota Kupang”. Jurnal Teknik Sipil, 1(1): $41-51$ (in Indonesian).
69 Kinasih G, Wiriasto W, Kanata B and Zubaidah T (2014). "Lesser Sunda Islands Earthquake Inter-Occurrence Times Distribution Modeling". International Journal of Technology, 3: 242-250. https://doi.org/10.14716/ijtech.v5i3.610

70 Harmsen S (2007). "USGS Software for Probabilistic Seismic Hazard Analysis (PSHA)". USGS. (Unpublished Manuscript). 